\title{
The Disbanding of the SADC Tribunal: A Cautionary Tale
}

\author{
Laurie Nathan*
}

\begin{abstract}
In 2011 the heads of state of the Southern African Development Com-munity (SADC) disbanded the SADC Tribunal after the regional court held that the Zimbabwean government's land seizures violated the rule of law. The disbandment reflects SADC's hierarchy of values, in terms of which the organization's formal commitment to human rights and a regional legal order is subordinate to the political imperatives of regime solidarity and respect for sovereignty. The Tribunal saga demonstrates that the jurisdiction of regional courts derives not simply from their official mandates but from an interplay between domestic and regional law and politics.
\end{abstract}

\section{INTRODUCTION}

Many scholars view the adoption of human rights instruments by regional organizations in Africa as a significant development. ${ }^{1}$ These scholars believe that these instruments indicate growing acceptance of human rights principles by African governments and that the instruments will themselves promote

* Laurie Nathan is Extraordinary Professor and Director of the Centre for Mediation in Africa at the University of Pretoria. The research undertaken for this article was funded by the Konrad Adenauer Stiftung.

The views expressed herein are solely those of the author.

1. See, e.g., Gavin Cawthra, Collaborative Regional Security and Mutual Defence: SADC in Comparative Perspective, 35 Politikon 159 (2008); Bronwen Manby, The African Union, NEPAD, and Human Rights: The Missing Agenda, 26 Hum. RTs. Q. 983 (2004); Jeremy Sarkin, The African Commission on Human and People's Rights and the Future African Court of Justice and Human Rights: Comparative Lessons from the European Court of Human Rights, 18 South Afr. J. Of INT'L Affairs 281 (2011). 
adherence to the principles. ${ }^{2}$ This is especially the case where the declaratory texts are buttressed by regional courts-such as the Community Court of Justice of the Economic Community of West African States (ECOWAS) and the Tribunal of the Southern African Development Community (SADC)—which appear to afford citizens a means of protecting their rights against infringement by governments. The academic literature on these institutions, while recognizing their flaws and limitations, depicts a process of incremental progress towards greater realization of human rights on the continent. ${ }^{3}$

The story of the SADC Tribunal confounds this optimistic perspective. ${ }^{4}$ In 2008 the Tribunal ruled that the Zimbabwean government's seizure of land owned by white farmers violated the SADC Treaty principles on nondiscrimination and the rule of law. ${ }^{5}$ The court ordered the government to refrain from interfering with the farmers' occupation and ownership of their properties. The government spurned the court, continued to subject the farmers to violent harassment and mounted a campaign to emasculate the Tribunal and nullify its rulings. Instead of upholding the Treaty and defending the Tribunal, in 2011 the SADC Summit of heads of state suspended the regional court. This move effectively dissolved the court and was roundly criticized by lawyers' associations and human rights groups. ${ }^{6}$

The first part of this article presents an overview of SADC's legal edifice, the Tribunal's decisions on Zimbabwe, and the disbanding of the court. The second part analyzes the disbandment and explores the contradiction between the construction of a legal framework endorsing human rights and the refusal by member states to adhere to this framework. The third part examines the Tribunal saga in comparative perspective, discussing the factors that determine whether states comply with the human rights judgments of regional courts.

2. For a comprehensive overview of the human rights instruments of the African Union and the sub-regional organizations on the continent, see Frans Viljoen, International Human Rights LaW in Africa (2007).

3. See, e.g., Lucyline Murungi \& Jacqui Gallinetti, The Role of Sub-Regional Courts in the African Human Rights System, 7 SUR INT'L J. Hum. RTs. 119 (2010); Solomon Ebobrah, Human Rights Developments in Sub-Regional Courts in Africa During 2008, 9 Afr. Hum. RTs. Law J. 312 (2009); Daniel Hemel \& Andrew Schalkwyk, Tyranny on Trial: Regional Courts Crack Down on Mugabe's Land "Reform," 35 Yale J. INT'L Law 517 (2010).

4. The SADC states are Angola, Botswana, the Democratic Republic of the Congo, Lesotho, Malawi, Mauritius, Mozambique, Namibia, Seychelles, South Africa, Swaziland, Tanzania, Zambia, and Zimbabwe. Madagascar's membership was suspended following a coup in 2009.

5. Mike Campbell (Pvt) Ltd. and Others v. Republic of Zimbabwe (2008), SADCT 2/2007 (prior to this judgment, in late 2007 the Tribunal issued an interim ruling in favor of the farmers affirming its jurisdiction in the matter). See Hemel \& Schalkwyk, supra note 3.

6. See, e.g., International Commission of Jurists, Southern Africa litigation Centre \& SADC Lawyers' Association, Resolutions of SADC Lawyers, Judges and Rule of Law Advocates Adopted at the 2nd Regional Legal Consultative Conference on the Review of the SADC Tribunal (2011). 
The dissolution of the Tribunal reflects SADC's hierarchy of values, in terms of which the organization's formal commitment to human rights, the rule of law, and a regional legal order is subordinate to the political imperatives of regime solidarity and respect for sovereignty. The crux of the matter is that the SADC states will not relinquish sovereignty to regional institutions. Scholars who have described the Tribunal as a supranational entity are mistaken. ${ }^{7}$ The establishment of such entities entails the "formal transfer of legal authority and decision-making power from member states to an institution or international body." ${ }^{\prime 8}$ This has not occurred in Southern Africa, partly because many of the SADC states have only a weak grip on sovereignty and are thus disinclined to dilute it and partly because their diverse political systems, ranging from democratic to authoritarian, make it impossible for them to reach consensus on communal norms regarding domestic governance.

The demise of the Tribunal serves as a cautionary tale, demonstrating that the jurisdiction of regional courts derives not simply from their official mandates but also from the response of member states when a court rules against one of them. In addition, the SADC experience is a salutary reminder that any assessment of progress in the field of human rights on the continent should be based on the way in which states treat their citizens rather than on the existence of regional human rights instruments and mechanisms.

\section{THE RISE AND FALL OF THE TRIBUNAL}

\section{A. SADC's legal order}

Since its formation in 1992, SADC has built an elaborate legal edifice centered on a founding treaty ${ }^{9}$ and buttressed by protocols on politics and security, extradition, mining, energy, health, education, gender, and other topics. ${ }^{10}$ The protocols are drafted by the SADC Secretariat with the assistance of technical experts and lawyers, negotiated by government officials and ministers,

7. For examples of such scholars, see, e.g., Murungi \& Gallinetti, supra note 3; Ebobrah, supra note 3; Tobias Lenz, Spurred Emulation: The EU and Regional Integration in Mercosur and SADC, 35 W. Eur. Pol. 155 (2012); Monica Kaminska \& Jelle Visser, The Emergence of Industrial Relations in Regional Trade Blocks-A Comparative Analysis, 49 Brit. J. Industrial Rel. 256 (2011).

8. Andrew Hurrell, Supranationalism, in The Concise Oxford Dictionary of Politics (lain McLean \& Alistair McMillan eds., 2009).

9. Treaty of the Southern African Development Community (1992), available at http://www. sadc.int/documents-publications/sadc-treaty/ [hereinafter SADC Treaty 1992].

10. Id. 
discussed and approved by the Summit, and signed by the heads of state. They are then subject to ratification by member countries. This process and the resultant texts create the impression that the SADC states believe that formal rules are required to achieve the organization's objectives regarding regional integration, that they have agreed to be bound by the rules, and that they are committed to human rights and democratic norms.

The Treaty stipulates that SADC and its members must act in accordance with the principles of sovereign equality of states; solidarity, peace, and security; human rights, democracy, and the rule of law; equity, balance, and mutual benefit; and peaceful settlement of disputes. ${ }^{11}$ The signatory states undertake to refrain from taking measures likely to jeopardize the sustenance of these principles, the achievement of the communal objectives, and the implementation of the Treaty. ${ }^{12}$ They must take all steps necessary to accord the Treaty the force of national law. ${ }^{13}$ Sanctions may be imposed on a member that persistently fails, without good reason, to fulfill its Treaty obligations or implements policies that undermine SADC's principles and objectives. ${ }^{14}$ The Tribunal is an institution of SADC intended to adjudicate upon disputes between states and ensure adherence to the Treaty. ${ }^{15}$

When the Treaty was amended in 2001, the formal commitment to democracy was strengthened through the addition of an article proclaiming that one of SADC's objectives is to "consolidate, defend and maintain democracy, peace, security and stability." ${ }^{16}$ In the same year the Summit approved a protocol on regional security mandating the SADC Organ on Politics, Defence and Security Co-operation to promote the "development of democratic institutions and practices within the territories of State Parties and encourage the observance of universal human rights as provided for in the Charters and Conventions of the Organisation of African Unity and the United Nations respectively."17 SADC's Regional Indicative Strategic Development Plan maintains that democracy is a precondition for stability and economic development and growth, which "will not be realised in conditions of political intolerance, the absence of the rule of law, corruption, civil strife and war." ${ }^{\prime 18}$

The establishment of the Tribunal in 2005 reinforced the impression that member states were willing to be bound by SADC's principles and subordi-

\footnotetext{
11. Id. art. 4.

12. Id. art. 6 .

13. Id.

14. Id. art. 33.

15. Id. arts. 9, 16 .

16. SADC, Agreement Amending the Treaty of the Southern Africa Development Community, art. 5(a) (2001).

17. SADC, Protocol on Politics, Defence and Security Co-operation, art. 2(g) (2001).

18. SadC, Regional Indicative Strategic Development Plan 5 (2003).
} 
nate their sovereignty to regional institutions. In 2000, the Summit approved the Protocol for the Tribunal, and five years later the court was inaugurated in Windhoek, Namibia. The Tribunal's jurisdiction covers disputes between states, and between natural or legal persons and states, over the interpretation and application of the Treaty and protocols. ${ }^{19}$ No person may bring an action against a member state unless he or she has exhausted all available domestic remedies or is unable to proceed under the relevant domestic jurisdiction. ${ }^{20}$ Where a party refers a dispute to the Tribunal, the consent of the other parties to the dispute is not required. ${ }^{21}$ The court's judgments are final and binding on the parties to the dispute. ${ }^{22}$ The signatory states must enforce these judgments in accordance with their laws on the registration and enforcement of foreign judgments and they "shall take forthwith all measures necessary to ensure execution of the decisions of the Tribunal."23 If a state fails to comply with a ruling of the Tribunal, the court shall report such failure to the Summit for "appropriate action". ${ }^{24}$ The court comprises jurists who are nationals of SADC countries, selected by the Summit on the basis of nominations by member states. ${ }^{25}$

While the Tribunal does not have enforcement powers, it is evident from the above that the SADC states are expected to abide by and give effect to the court's rulings and that failure to do so must be addressed by the Sum-mit. Between 2007 and 2010 the enforceability of the Tribunal's decisions was put to the test in a series of cases challenging the Zimbabwean govern-ment's harassment of white farmers and seizure of their farms and land. As discussed below, the Summit failed the test dismally, turning its back on the Tribunal and the Treaty.

\section{B. The Tribunal and Zimbabwe}

In 2000 Zimbabwean war veterans who had fought in the liberation struggle during the 1970s embarked on a violent campaign of invading and occupying white-owned land and farms. The land question had long been a smoldering political and economic problem. In the late 1990s acute racial inequities in land ownership_-arising from colonial conquest and white minority rule and then entrenched by Zimbabwe's negotiated settlement in 1979—still in place. ${ }^{26}$ The government backed the land

19. SADC, Protocol on the Tribunal and Rules Thereof, arts. 14 \& 15 (2000).

20. Id. art. 15 .

21. Id.

22. Id. art. 24.

23. Id. art. 32 .

24. Id.

25. Id. arts. 3, 4. 
invasions and launched a program of compulsory land expropriations. The program was characterized by disregard of judicial rulings, the emasculation of the judiciary, violence perpetrated by state-sponsored militia, the accumulation of farms by the ruling elite, and the immiseration of thousands of black farm workers. ${ }^{27}$

In 2007 a group of white Zimbabwean farmers petitioned the SADC Tribunal for relief over the government's confiscation of their farms (hereinafter the "Campbell case"). The confiscations had taken place under the terms of a constitutional amendment enabling the state to expropriate agricultural land for resettlement and other purposes (hereinafter Amendment 17). ${ }^{28}$ "Amendment 17" excludes from the jurisdiction of the Zimbabwean courts any plea contesting such expropriation. When the Tribunal heard the Campbell case, it noted that the Zimbabwean Supreme Court had recently denied Campbell and the other applicants the right to institute domestic proceed-ings objecting to the seizure of their land. The Supreme Court had accepted that its jurisdiction to hear the matter had been ousted by Amendment 17. Consequently, the Tribunal held that the applicants did not have domestic legal remedies available to them and were entitled to lodge their complaint with the regional court. ${ }^{2}$

The Tribunal ruled that the Zimbabwean government was in breach of the Treaty because the ouster clause in "Amendment 17" violated two essential elements of the rule of law, namely the right of access to the courts and the right to a fair hearing before being deprived of a right, interest, or legitimate expectation. ${ }^{30}$ The Tribunal also found that "Amendment 17" targeted white farmers alone and did so regardless of other factors such as their citizen-ship, length of residence in Zimbabwe, and proper use of their lands. The constitutional amendment thus amounted to indirect racial discrimination, which was contrary to the Treaty and many international conventions. ${ }^{31}$ The Tribunal added that it would have reached a different conclusion if the state's criteria in confiscating land had been reasonable and objective, if fair compensation had been paid for expropriated lands, and if these lands had been "distributed to poor, landless and other disadvantaged individuals or groups." ${ }^{\prime \prime 2}$ The Tribunal ruled that the state should pay the farmers fair

26. Sam Moyo \& Prosper Matondi, The Politics of Land Reform in Zimbabwe, in From CAPE to Congo: Southern Africa's evolving security challenges 73 (Mwesiga Baregu \& Christopher Landsberg eds., 2003); Neil Thomas, Land Reform in Zimbabwe, 24 THIRD WorLD Q. 691 (2003).

27. International Crisis Group (ICG), Zimbabwe: Time for International Action, 5 AfrICA BRIEFING (2001).

28. Constitution of Zimbabwe Amendment Act (No. 17) (2005).

29. Mike Campbell v. Republic of Zimbabwe, supra note 5.

30. Id.

31. SADC Treaty 1992, supra note 10, art. 6(2), prohibits discrimination on grounds of race and other biological and social factors.

32. Mike Campbell v. Republic of Zimbabwe, supra note 5. 
compensation for their expropriated land. It ordered the government to take all necessary measures to protect the possession, occupation, and ownership of the applicants' other land and to ensure that no action was taken to evict the farmers or interfere with their peaceful residence of their properties.

President Robert Mugabe dismissed the Tribunal's judgment as an "exercise in futility." ${ }^{\prime 33}$ When some of the applicants were beaten up and tortured in 2008, they urgently petitioned the Tribunal to hold the government in breach and contempt of the regional court's order. ${ }^{34}$ The Tribunal ruled in their favor, rejecting the government's defense that there was a state of lawlessness in Zimbabwe and that the authorities were experiencing difficulty in preventing intimidation and violence. ${ }^{35}$ In 2009 the farmers turned to the Tribunal for a further declaration that the government was in breach of the Tribunal's order. This time the government declined to participate in the proceedings. The court noted that Mugabe had described its earlier decisions as "nonsense" and "of no consequence" and that these remarks had been followed by the intimidation and prosecution of the farmers and the invasion of their land. ${ }^{36}$ Once again the court found for the farmers.

Harare viewed the Tribunal's decisions as intolerable interference in the country's domestic affairs. In 2009 the Zimbabwean Minister of Justice, Patrick Chinamasa, announced that his government had withdrawn from the Tribunal's jurisdiction. He argued that the regional court was not legally constituted because its Protocol had not been ratified by two-thirds of the member states, a requirement that he said was stipulated in the Protocol. ${ }^{37}$ Chinamasa did not explain why, nine years after Mugabe had signed the Protocol, Zimbabwe had yet to ratify the document. Chinamasa's argument implied that the government could legitimately evade the Tribunal's jurisdiction because of the government's own failure to table the Protocol for ratification by parliament.

Furthermore, Chinamasa relied on an outdated version of the Protocol. When the Summit revised the Treaty in 2001, it scrapped the requirement that the Tribunal Protocol would only come into force after ratification by two-thirds of the member states. Instead, the Protocol would be incorpo-

33. Mugabe Says Tribunal Ruling on White Farms "Exercise in Futility," Newzimbabwe.com, 5 Dec. 2008, available at http://www.newzimbabwe.com/pages/farm77.19109.html.

34. In April 2011 Mike Campbell, the leading applicant in the Campbell case, died as a result of the brain injuries he sustained during the 2008 assault. The express purpose of the assault, perpetrated by youth militia aligned to the ruling party, was to force Campbell to withdraw his case from the Tribunal. See Without a Trace, ZIMBABWEAN, 12 Apr. 2011 available at http://www.thezimbabwean.co.uk/articles/38864/without-a-trace-.html.

35. Mike Campbell (Pvt) Ltd. v. Republic of Zimbabwe (2008), SADCT 11/2008.

36. Campbell and Another v. Republic of Zimbabwe (2009) SADCT 3/2009.

37. Mabasa Sasa, Zim Pulls out of SADC Tribunal, Herald (Zimbabwe), 2 Sept. 2009, available at www.zimbabwesituation.com/sep3_2009.html. 
rated into the Treaty and would enter into force on the date on which the Agreement Amending the Treaty of the Southern African Development Community entered into force by virtue of its adoption by three-quarters of the members. ${ }^{38}$ In August 2001 the Agreement was duly adopted and signed by thirteen heads of state, including Mugabe. The Tribunal Protocol thus came into force on that date. The Summit subsequently amended the Protocol so as to reflect this change and other modifications to the court. ${ }^{39}$

In response to Chinamasa, the lawyers representing the Zimbabwean farmers cited international case law and the law of treaties to insist that a state may not act contrary to a treaty it has consented to but not ratified..$^{40}$ Nor may a state invoke its constitution and other domestic law as an excuse to dishonor a treaty obligation. ${ }^{41}$ The lawyers added that it is a well-known principle of international law and domestic legal systems, including that of Zimbabwe, that once jurisdiction is established in a given matter it cannot be lost, least of all on the basis of a unilateral and belated disavowal of jurisdiction by one of the parties. Moreover, the Zimbabwean government had nominated a judge to serve on the Tribunal and had relied extensively on the provisions of the Protocol during many of the Tribunal's hearings. This exposed Chinamasa's subsequent disavowal of the Protocol's validity as "humbug and a contrivance." 42 Chinamasa's position also drew a scathing denunciation from the Pan-African Lawyers' Union, the African Regional Forum of the International Bar Association, and the International Commission of Jurists. ${ }^{43}$

On three occasions the Tribunal referred Zimbabwe's failure to obey its rulings to the Summit for appropriate action and on each occasion the Summit declined to act. For Zimbabwe the Summit's passivity was not sufficient, however. The government also wanted to ensure that the Tribunal's rulings were rendered void. To this end, Chinamasa successfully lobbied his ministerial counterparts in other SADC countries to support Harare's stance. In 2010, after the annual Summit meeting, he announced that the heads of state had suspended the Tribunal for six months pending the outcome of

38. SADC, Agreement Amending the Treaty of the Southern African Development Community, arts. 18, 32 (2001).

39. SADC, Agreement Amending the Protocol on Tribunal (2002).

40. The Zimbabwe Situation, A Reply to the Chinamasa Response, from the CFU's Lawyers (20 Sept. 2009), available at http://www.zimbabwesituation.com/sep20_2009.html [hereinafter Reply to Chinamasa Response].

41. Vienna Convention on the Law of Treaties, art. 27, U.N. Doc. A/CONF.39/27 (1969), 1155 U.N.T.S. 331 (entered into force 27 Jan. 1980), reprinted in 8 I.L.M. 679 (1969) states that "[a] party may not invoke provisions of its internal law as justification for failure to perform a treaty."

42. Reply to Chinamasa Response, supra note 41.

43. African Bar Associations \& Rule of Law Institutions, Arusha Communiqué, Chinamasa Criticised for Attack on SADC Tribunal, SW RADIo AfrICA, 16 Sept. 2009, available at http://www.swradioafrica.com/pages/chinamasa160909.htm. 
a review by the region's justice ministers and attorneys general. ${ }^{44}$ Mugabe proclaimed that the suspension amounted to the nullification of the court's decisions against Zimbabwe. ${ }^{45}$

Following the 2010 Summit meeting, the SADC Secretariat commissioned an independent review of the Tribunal. Undertaken by Lorend Bartels from the University of Cambridge, the review affirmed the jurisdiction of the Tribunal and vindicated its decisions. ${ }^{46}$ Bartels' main conclusions were as follows: the Tribunal has the legal authority to deal with individual human rights petitions; SADC law should be supreme in relation to domestic laws and constitutions; decisions of the Tribunal were binding and enforceable within the territories of member states; the Tribunal was lawfully established in terms of the Tribunal Protocol; the SADC countries waived the requirement to ratify the Protocol, which became part of the Treaty by agreement and binding on all member states; Zimbabwe's participation in the Tribunal's proceedings and nomination of a judge to serve on the court preclude it from arguing that the Tribunal was not legally constituted; and a state may not rely on its constitution and national laws as a defense against a violation of an international obligation. ${ }^{47}$

Notwithstanding these conclusions, in 2011 the Summit announced that it would maintain the moratorium on the regional court hearing any extant, pending, or new case until the Tribunal Protocol had been reviewed and the revisions approved by the heads of state. ${ }^{48}$ It mandated the region's ministers of justice and attorneys general to initiate a process of amending the relevant SADC legal instruments. The Summit resolved further that it would not reappoint or replace the Tribunal judges whose term of office ended in 2010 or 2011. This move rendered the court inquorate and inoperative.

The Tribunal judges wrote an angry letter to the Executive Secretary of SADC, arguing that the Summit's decision amounted to dissolving and not merely suspending the court. ${ }^{49}$ This decision was illegal, ultra vires, and taken

44. Caesar Zvayi, Southern African Development Community Tribunal Suspended, HeRAlD (Zimbabwe), 17 Aug. 2010, available at http://panafricannews.blogspot.com/2010/08/ south-african-development-community.html.

45. Mugabe Insists SADC Tribunal "Has Been Suspended," ZIMEYE, 23 Aug. 2010, available at http://www.zimeye.org/?p=21146.

46. SADC Law Binding: Independent Review Ratifies Land Grab Decision, Zimbabwean, 13 Apr. 2011, available at http://www.thezimbabwean.co.uk/index.php?option=com_cont ent\&view=article\&id=38881: sadc-law-binding\&catid=69: sunday-top-stories\&ltemid=30.

47. Id.

48. SADC, Communiqué, Extraordinary Summit [of] Heads of State and Government of the Southern Africa Development Community, Windhoek (20 May 2011).

49. Ariranga Pillay, Rigoberto Kambavo, Onkemetse Tshosa \& Frederick Chomba, Three IIlegal and Arbitrary Decisions Taken in Bad Faith by the SADC Council of Ministers and Summit of Heads of State and Government, Letter to the Executive Secretary of SADC (13 June 2011), available at http://www.politicsweb.co.za/politicsweb/view/politicsweb/ en/page71656? oid=242579\&sn=Detail\&pid $=71616$. 
in bad faith. While the Summit was at liberty to amend the Treaty and the Tribunal Protocol according to the prescribed procedures, prior to making such amendments it could not legitimately limit the Tribunal's jurisdiction, to which the Summit itself was subject, and it could not legitimately stop the Tribunal from hearing the cases before it. The judges concluded that the Summit's action was a breach of the Treaty and the right of access to justice.

A noteworthy postscript to this story is provided by a judgment of the Pretoria High Court in 2011. Some of the Campbell applicants had appealed to the Court to enforce the Tribunal's decision to award legal costs to them; this could be done by attaching and selling property that the Zimbabwean government owned in South Africa. The Court supported their plea, rejecting the government's claim that it had not ratified the Tribunal Protocol and was therefore not bound by the Tribunal's decisions. ${ }^{50}$ The Court held that the government had participated in the Tribunal's proceedings in the Campbell case in 2007; its acting attorney general had admitted during those proceedings that Zimbabwe was bound by the Tribunal's rulings; Zimbabwe had nominated one of its own judges to serve on the regional court; the SADC heads of state had dropped the requirement that the Protocol be ratified before coming into force; and Zimbabwe, having signed and adopted the SADC Treaty, could not now renege on its obligation to adhere to it. The Zimbabwean government launched an unsuccessful appeal against this judgment, the South African appellate division upholding the decision of the Pretoria court. ${ }^{51}$ These judgments were a small victory for the farmers and the rule of law, but the larger battle had already been lost with the Summit's disbandment of the Tribunal.

\section{ANALYSIS}

The professed legal character of the Treaty and protocols, coupled with the formation of a regional court empowered to make binding decisions, created the illusion that the SADC countries were willing to be constrained by communal rules and relinquish some sovereignty to a supranational authority. This illusion was shattered by Zimbabwe's defiance of the Tribunal and the Summit's acquiescence and subsequent disbanding of the court. The discussion that follows aims to explain the contradiction between the construction of an elaborate legal framework embracing human rights and the refusal by member states to respect their own regional instruments. The

50. Government of the Republic of Zimbabwe v. Louis Karel Fick, North Gauteng High Court (2011), available at http://www.kubatana.net/html/archive/landr/110606nghc.asp.

51. SA Supreme Court Dismisses Zimbabwe Appeal, S. Afr. Press Assn, 20 Sept. 2012, available at http://www.zimeye.org/?p=62867. 
analysis focuses on sovereignty, the nature of shared values among SADC countries, the dependence of these countries on foreign donors, and the political imperative of state solidarity.

\section{A. No Surrender of Sovereignty}

In the early 1990s the economists and other technical experts who drafted SADC's founding documents were aware that regional integration posed a challenge to the sovereign decision-making authority of states. This had become evident from both the poor performance of SADC's predecessor, the Southern African Development Co-ordination Conference, and the positive experience of regional integration in other parts of the world. The 1992 SADC Declaration observed that integration required "strengthening the powers and capacity of regional decision-making, coordinating and executing bodies." ${ }^{52}$ The document was at pains to point out, however, that this entailed a shift in the locus and context of exercising sovereignty rather than a loss of sovereignty. ${ }^{53}$

For two compelling reasons, the SADC countries have been implacably opposed to any transfer of sovereignty to the regional level. First, many of the countries gained their independence relatively recently and at great cost through liberation struggles. Moreover, the acquisition of de jure sovereignty has not led to the attainment of full empirical sovereignty: the states do not have comprehensive administrative control over their territories; they are unable to stem the flow of people and contraband across their borders; they have not at all times had a monopoly on the use of force; and their ability to mobilize resources and collect taxes is limited. Their national authority is further undermined by the economic and financial dimensions of globalization and by the prescriptions of foreign donors. States with a tenuous grip on sovereignty are naturally opposed to diluting it even more through binding regional rules and decision-making and enforcement mechanisms.

Second, the SADC countries have not achieved the Treaty objective of "evolv[ing] common political values, systems and institutions." ${ }^{54}$ On the contrary, their political dispensations cover the spectrum from authoritarian to democratic. According to the Freedom House survey of political rights and civil liberties, in 2009 Angola, the Democratic Republic of Congo, Swaziland, and Zimbabwe were "not free"; Lesotho, Madagascar, Malawi,

52. SADC, Towards the Southern African Development Community: A Declaration by the Heads of State or Government of Southern African States 9 (1992), available at http://

53. Id. www.sadc.int/documents-publications/show/Declaration_Treaty_of_SADC.pdf.

54. SADC Treaty 1992, supra note 10, art. 5(b). 
Mozambique, Seychelles, Tanzania, and Zambia were "partly free"; and Botswana, Mauritius, Namibia, and South Africa were "free." ${ }^{55}$ In these circumstances it is not tenable for states to transfer sovereignty to regional institutions as none of the countries can be certain that communal rules and decisions will be consistent with its core values. The democratic states will not accept a regional order that obliges them to implement undemocratic measures and the same is true of authoritarian states with respect to democratic measures.

The consequent unwillingness of states to surrender sovereignty is evident in SADC's refusal to set up a collective system to monitor state compliance with the Treaty's provisions on domestic governance. In 1996 the Secretariat proposed that the new Organ on Politics, Defence and Security Co-operation should monitor state performance in the field of human rights, democracy, and the rule of law. ${ }^{56}$ The ministerial committee that reviewed the Organ's draft terms of reference dismissed this proposal as interference in domestic affairs. The ministers recommended instead that the Organ should monitor state ratification of international conventions on human rights. ${ }^{57}$ During the drafting of the Organ Protocol in 2000, even this mild recommendation was deemed too intrusive and all references to human rights monitoring were excised from the text. The final version of the document simply provides that one of the Organ's objectives is to encourage states to observe universal human rights as enshrined by the UN and the OAU. ${ }^{58}$ The potentially significant function of human rights monitoring was thus replaced with a vacuous expression.

Viewed in this light, it is not surprising that the Summit dissolved the Tribunal after the regional court ruled against Zimbabwe. The ruling posed a radical challenge to sovereignty, rejecting the validity of a constitutional provision approved by the Zimbabwean parliament and courts and refuting the lawfulness and legitimacy of the government's approach to redressing the land inequities inherited from colonialism and white settler rule. The surprising aspect of the Tribunal is that the Summit agreed in the first place to set up a regional court with a mandate that covered disputes between citizens and states in relation to the application of the Treaty and protocols. This puzzle is discussed below.

55. Freedom House, Table of Independent Countries [in 2009] (2010) available at http:// www.freedomhouse.org/report/freedom-world/freedom-world-2009.

56. SADC Secretariat, Terms of Reference for the SADC Sector on Political Cooperation, Democracy, Peace and Security, unpublished document prepared for the meeting of SADC ministers in Gaborone on 18-19 Jan. 1996. (On file with author.)

57. SADC Secretariat, The SADC Organ on Politics, Defence and Security: Meeting of SADC Ministers Responsible for Foreign Affairs, Defence and SADC Affairs, unpublished record of the meeting of the SADC ministers in Gaborone on 18-19 Jan. 1996. (On file with author.)

58. SADC, Protocol on Politics, supra note 18, art. 2(2)(g). 


\section{B. Accounting for the Democratic Framework and the Tribunal}

Why do SADC's legal instruments embrace human rights and democracy when its members are not collectively dedicated to democratic norms? The answer probably lies in a combination of factors: the hegemony of the democratic paradigm at the UN and in other international forums; the adoption of this paradigm in the declaratory texts of the OAU and the African Union, ${ }^{59}$ the economic weakness of SADC states, many of whose national and regional programs are dependent on development aid from Western donors that insist on adherence to democratic principles; and the absence of any penalty for failing to abide by the regional legal instruments. In this context it would make no sense for the Treaty and protocols to project an anti-democratic or less-than-democratic stance.

The extent of Southern Africa's economic weakness is captured by figures on Gross National Income (GNI). In 2003 the combined GNI of the fourteen SADC states was $\$ 185$ billion, of which South Africa accounted for 68 percent. The average GNI per capita was $\$ 1,711$ and seven countries had a GNI per capita of less than $\$ 600 .{ }^{60}$ As a result of the low level of development, SADC is reliant on donor assistance. In 2004 it received approximately 80 percent of its project funding from the European Union (EU) and other foreign sources, ${ }^{61}$ making it extremely vulnerable to donor leverage. This leverage is not hypothetical: in 2005 Western donors withdrew their support for the Regional Peacekeeping Training Centre, located in Harare but utilized as a shared SADC facility, because of Zimbabwe's human rights abuses. ${ }^{62}$

In 2011 as much as 72 percent of SADC's total budget of $\$ 83$ million was expected to come from foreign funders. ${ }^{63}$ The government

59. See, e.g., African Charter on the Rights and Welfare of the Child, adopted 11 July 1990, OAU Doc. CAB/LEG/24.9/49 (entered into force 29 Nov. 1999); Constitutive Act of the African Union, adopted 11 July 2000, CAB/LEG/23.15 (entered into force, 26 May 2001); African Charter on Democracy, Elections and Governance, adopted by the Eighth Ordinary Session of the Assembly, Addis Ababa, Ethiopia (30 Jan. 2007).

60. By way of comparison, in 2003 the GNI per capita was $\$ 2,250$ in the Middle East and North Africa, \$3,260 in Latin America and \$22,850 in the European Monetary Union. All GNI figures are drawn from the World Bank's World Development Indicators database, available at http://www.worldbank.org/data/quickreference/quickref.html.

61. Elling Tjønneland, Foreign Aid and Regional Co-operation, 4 SADC BAROMETER 15 (2004).

62. Study Team, SADC RPTC: Vision for the Future. Final Report of an Independent Study Commissioned by the Directorate of the SADC Organ on Politics, Defence and Security Cooperation (2008), available at http://www.apsta-africa.org/documentation/ general_downloads/sadcrptcmay08.pdf.

63. Press Release, Dept. Int'I Relations \& Cooperation, SA, Talking Notes by Hon. Dr Hage Geingob, Chairperson of the SADC Council of Ministers and Minister of Trade and Industry of the Republic of Namibia on the Occasion of Briefing the Media on the Outcome of the Meeting of the SADC Council of Ministers, Windhoek, Namibia, 4 Mar. 2011, available at http://www.dfa.gov.za/docs/speeches/2011/gein0304.html. 
newspaper in Zimbabwe, The Herald, concluded that "[if] he who pays the piper calls the tune, then Sadc is not in control of its affairs at all." ${ }^{64}$ More specifically, The Herald asserted that the "foreign-funded Tribunal" was a "Western project" and not an African one. It might seem overly cynical to view the establishment of the Tribunal as a donor-driven initiative, but there is good evidence to support this claim. Tobias Lenz draws on records of the SADC Council of Ministers to show that in the late 1990s the organization's donors had become increasingly dissatisfied with SADC's failure to meet its objectives, had threatened to cut their funding, and were calling for the creation of a dispute settlement mechanism that would press states to abide by their commitments. ${ }^{65}$ The drafters of the Tribunal Protocol, who included a British judge funded by the European Community, emulated the features of the European Court of Justice (ECJ) in order to alleviate these donor concerns and enhance the credibility of SADC's court and regional integration mission. ${ }^{66}$

Norman Tjombe, a Namibian human rights lawyer, maintains that the Summit was never enthusiastic about the Tribunal, taking fifteen years from the signing of the 1992 Treaty until the appointment of the Tribunal judges in 2007; throughout this period, "it was actually just international powers pushing for [the regional court]." ${ }^{67}$ Judge Ariranga Pillay, the former chief justice of Mauritius who headed the Tribunal at the time of its dissolution, shares Tjombe's opinion. Pillay believes that for SADC's leaders, the Tribunal was a gambit "to get funds from the European Union and others." 68

[The Tribunal] gave off all the right buzz words, you know, 'democracy, rule of law, human rights' - and then they [the leaders] got the shock of their lives when we said these principles are not only aspirational but also justiciable and enforceable. ${ }^{69}$

Pillay is suggesting here that the Summit set up the regional court without imagining that it would actually function as a supranational authority and declare invalid the laws and policies of a member state. In 2011 Mugabe implied as much when commenting on the Summit's disbandment of the court: "We are the creators of this monster and we said we thought we had created an animal which was proper, but no, we had created a monster." ${ }^{\prime 70}$

64. Southern Africa: SADC Must Wean Itself from Donors, Control Own Budget, HeRALD (Zimbabwe), 19 Aug. 2011, available at http://allafrica.com/stories/201108190363.html.

65. Lenz, supra note 8.

66. Id.

67. Sean Christie, The SADC Tribunal's Last Gasp, MaIL \& Guardian, 10 June 2011, available at http://mg.co.za/article/2011-06-10-the-sadc-tribunals-last-gasp.

68. Sean Christie, Killed off by "Kings and Potentates," Mall \& Guardian, 19 Aug. 2011, available at http://mg.co.za/article/2011-08-19-killed-off-by-kings-and-potentates.

69. Id.

70. Mugabe Insists SADC Tribunal, supra note 46. 
The broader point is that the authoritarian countries of Southern Africa were prepared to sign the Treaty and protocols because they did not foresee any negative consequences emanating from this. They paid no heed to the legal instruments and the Summit refrained from criticizing and taking action against them when they breached those instruments. Indeed, as discussed below, when the Zimbabwean government became the subject of international sanctions on account of its human rights abuses, the SADC heads of state closed ranks in solidarity with it.

\section{Solidarity Trumps Democracy}

In addition to the principle of respect for sovereignty, the predominant norms of SADC are regime solidarity and anti-imperialism. These norms were forged in blood in the 1970s and 1980s as the Southern African liberation movements battled collectively against colonial rule, minority regimes, and the Western allies of those regimes. In the post-colonial period, the salience of these norms has been reinforced by the West's prescriptive policies in Africa, domination of the UN Security Council and other international forums, and selective stance on human rights and the use of force.

From an anti-imperialist perspective, human rights are relevant not only in terms of individual entitlements and domestic politics, but also in terms of the global struggle between the North and the South. According to Dumisani Kumalo, South Africa's ambassador to the UN during the presidency of Thabo Mbeki, the developed and developing nations are "locked in a 'cold war' on the correct approach to human rights." 71 The developed countries are guilty of "double standards, hypocrisy, and the abuse of the UN's human rights machinery to serve national political agendas." ${ }^{72}$ When these countries take aim at the human rights record of selected states in the South, the developing states "are forced to rally to the support of the targeted country, irrespective of its actual human rights performance." ${ }^{13}$ Solidarity is thus an ideological commitment and a pragmatic response by the weak against the powerful.

The most striking manifestation of this tendency in SADC has been the Summit's position on Zimbabwe. Since 2000 the Zimbabwean government, faced with the prospect of losing power in an election, has suppressed domestic opposition through violence, intimidation, manipulation of elections, and denial of political rights. ${ }^{74}$ In its public statements the Summit's posture

71. Anthoni van Nieuwkerk, A Critique of South Africa's Role on the UN Security Council, 14 South Afr. J. INt'L Affairs 61, 72 (2007).

72. Id.

73. Id.

74. See, e.g., ICG, supra note 28; ICG, Post-Election Zimbabwe: What Next?, 93 Africa RePort (2005); ICG, Zimbabwe: Prospects from a Flawed Election, 138 Africa Report (2008). 
has been one of solidarity with Harare. The heads of state downplayed the human rights abuses, decried the "distorted" media reports on Zimbabwe, turned a blind eye to the electoral malpractices, and condoned the violent land seizures. ${ }^{75}$ Through the communiqués issued by the Summit, even the democratic members of SADC condemned the West for pressurizing Harare to respect human rights and the rule of law. The bottom line was encapsulated in the 2003 communiqué: at a time of intense repression in Zimbabwe, the Summit reiterated its rejection of sanctions and "re-affirmed the indivisibility of SADC and solidarity with Zimbabwe."76

Botswana is the only SADC country consistently to have taken a firm stand against Harare's violations of its Treaty obligations, refusing, for example, to recognize Mugabe's retention of the presidency after deeply flawed elections in 2008. ${ }^{77}$ South Africa, on the other hand, abandoned the democratic principles enshrined in the Treaty and its own constitution in favor of anti-imperialist solidarity. While critical of Mugabe, then South African President Mbeki was more agitated by the historical role of Western countries as colonial powers, their recent contributions to the land crisis in Zimbabwe, and their condescension in telling Africans how to behave. ${ }^{78}$ He bemoaned the fact that the core issue of land "has disappeared from public view" and "[i]ts place has been taken by the issue of human rights." For Mbeki and most of the SADC heads of state, the land crisis was vastly more important than the human rights crisis, with the latter portrayed as a misplaced concern of the West rather than a legitimate concern of the Zimbabwean people. ${ }^{80}$

When Harare not only defied but also sought to annul the Tribunal's rulings on land seizures in Zimbabwe, the Summit faced a stark choice: it could either defend the Treaty and the regional court, or it could support a member state whose president and ruling party had liberated their country from colonialism and thereafter assisted other liberation movements in Southern Africa. The decision to back Zimbabwe reflected SADC's hierarchy of

75. See, e.g., SADC, SADC Heads of State and Government Support Zimbabwe, Windhoek (7 Aug. 2000); SADC, SADC Summit Final Communiqué, 14 Aug. 2001, Blantyre; SADC, Final Communiqué, January 2002 SADC Extra-ordinary Summit of Heads of State and Government (14 Jan. 2002), Blantyre; SADC, 2003 SADC Summit Final Communiqué, Dar es Salaam (26 Aug. 2003).

76. Id. $\Upsilon 24$.

77. Botswana Breaks Ties with Zimbabwe, Afrol News, 3 July 2008 available at http://afrol. com/articles/29681.

78. Thabo Mbeki, Letter from the President: We Will Resist the Upside-Down View of Africa, 3 ANC Todar, 12-18 Dec. 2003 available at http://www.anc.org.za/docs/anctoday/2003/ at49.htm.

79. Id

80. See laurie Nathan, Community of Insecurity: SADC's Struggle for Peace and Security in Southern Africa 76-81 (2012). 
values, in terms of which sovereignty and regime solidarity take precedence over human rights and democracy. A complementary interpretation is that state interests prevail over the regional legal edifice. In 2011 the Namibian Minister of Justice, Pendukeni livula-Ithana, made this point explicitly, explaining that the Tribunal was under review so that it better served the interests of member states: "What is cast in stone is our commitment to work together as a regional body, SADC. How we do so is not cast in stone and should suit our collective interest. The instruments serve us, they are for us, and this is not a reversible position." ${ }^{81}$

It is likely that the Summit will replace the Tribunal with a quasi-legal body charged with adjudicating interstate disputes on trade and other regional integration matters that do not impinge on domestic governance and politics. When Chinamasa called for the suspension of the Tribunal in 2010, he maintained that it was a necessary instrument for integration but that it should only deal with questions referred to it by states. It had to be reconstituted in order to put it "on a sound footing which recognises negotiations between member countries over those issues member countries want to refer to the tribunal." ${ }^{82}$ This indeed was the position taken by the Summit in 2012 when it stated that the mandate of the new body "should be confined to interpretation of the SADC Treaty and Protocols relating to disputes between Member States." 83 In this arrangement, the citizens of Southern African states would not have recourse to the regional court and democratic principles would be excluded from its ambit.

\section{COMPARATIVE PERSPECTIVE ON THE IMPLEMENTATION OF REGIONAL JUDICIAL DECISIONS}

Zimbabwe's breach of its international legal commitments is not unique. Repressive regimes frequently sign regional and international human rights treaties and then fail to honor their obligations. ${ }^{84}$ Similarly, the problem of states failing to give effect to the human rights judgments of regional courts is a worldwide phenomenon. ${ }^{85}$ In many instances, though, the judgments are implemented. ${ }^{86}$ The mixed record is evident, for example, in the statistics on

81. John Ekongo, SADC Tribunal Should Serve Our Interests, New ERA, 27 July 2011.

82. Zvayi, supra note 45, at 2-3.

83. SADC, Final Communiqué of the 32nd Summit of SADC Heads of State and Government, Maputo ๆ 24 (18 Aug. 2012).

84. Emilie Hafner-Burton \& Kiyoteru Tsutsui, Justice Lost! The Failure of International Human Rights Law to Matter Where Needed Most, 44 J. Peace Research 407 (2007).

85. Open Society Justice Initiative (OSJI), From Judgment to Justice: Implementing International and Regional Human Rights Decisions (2010).

86. Id. 
compliance with judgments of the Inter-American Court of Human Rights: between 2001 and 2006 the remedies ordered by the court had a 29 percent rate of total implementation, a 12 percent rate of partial implementation, and a 59 percent rate of non-implementation. ${ }^{87}$

The Open Society Justice Initiative (OSJI) notes that while scholars have examined extensively the issue of state compliance with international human rights conventions, relatively little attention has been paid to the degree to which, and the conditions under which, states comply with the rulings of the legal and quasi-legal bodies set up to enforce these conventions. ${ }^{88}$ The lacuna prompted the OSII to conduct a study of state implementation of judicial and quasi-judicial decisions in the human rights systems of the UN, Africa, America, and Europe. The following discussion draws on the study in order to view the SADC experience from a comparative perspective.

There appear to be a number of critical factors that effect state implementation of the human rights decisions of regional courts. The first and most significant is the political character of the state. As one might expect, states that generally have a poor human rights performance also have a poor record of complying with the human rights judgments of regional and international courts. ${ }^{89}$ Likewise, there appears to be a positive correlation between countries that have a strong rule of law tradition and those that adhere to international judgments..$^{90}$ In the case of Zimbabwe, it was hardly surprising that the government, having systematically violated human rights and the rule of law in the national arena for over a decade, ${ }^{91}$ spurned the rulings of the regional court.

Second, the prospect of implementing regional court judgments is heightened where a country has introduced domestic legislation that mandates a national institution, typically a parliamentary committee or a statutory human rights organization, to monitor adherence to adverse judgments. The model institution in this regard is the United Kingdom's Parliamentary Joint Select Committee on Human Rights, established in terms of the Human Rights Act of 1998 in order to promote alignment with the European Convention on Human Rights. ${ }^{92}$ In the Inter-American human rights system, Peru has the most comprehensive national implementation legislation, which regulates the procedure for the execution of sentences issued by supranational courts

87. Id. at 65 .

88. Id. at 12 .

89. James Goldston, Achievements and Challenges_Insights from the Strasbourg Experience for Other International Courts, 5 Eur. Hum. Rts. L. Rev. 603, 608 (2009).

90. OSJI, supra note 84 , at 28.

91. Rhoda Howard-Hassmann, Mugabe's Zimbabwe, 2000-2009: Massive Human Rights Violations and the Failure to Protect, 32 Hum. RTs. Q. 898 (2010).

92. OSJI, supra note 84 , at 54-55. 
and outlines a process for resolving conflicts between the decisions of these courts and national law. ${ }^{93}$

No SADC country has promulgated legislation of this kind. The Tribunal's ruling against Zimbabwe underlined the need for such legislation to address, in particular, the constitutional and jurisdictional issues that arise when domestic courts are asked to give effect to regional court decisions. ${ }^{94}$ The significance of these issues was evident in the response of the Zimbabwean High Court in 2009 when it was approached by the Campbell applicants to register and enforce the Tribunal's ruling:

The supreme law in this jurisdiction is our Constitution and it has not made provision for these [Zimbabwean] courts to be subject to the tribunal. This court is a court of superior jurisdiction and has an inherent jurisdiction over all people and all matters in the country, and its jurisdiction can only be ousted by a statutory provision to that effect. . . . I do not have placed before me any statute to that effect and the [Tribunal] protocol certainly does not do that. ${ }^{95}$

The OSJI study indicates that a third category of critical factors concerns the import of the regional court's judgments. The more far-reaching a judgment is in terms of its substance, scope, or political sensitivity, the lower the probability that it will be implemented. ${ }^{96}$ The judgments least likely to be implemented include those that call for wholesale changes in legislation and policy and those that entail investigating and prosecuting gross human rights violations. The judgments most likely to be implemented include those that require the state to address the plight of a single individual, pay financial compensation to the victims of human rights abuses, or take symbolic action to acknowledge such abuses.

In the Campbell case the refusal by the Summit and the Zimbabwean courts to insist on compliance with the Tribunal's ruling was influenced strongly by the drastic constitutional, political, and social implications of that ruling. In 2010 the Zimbabwean High Court invoked these implications as the basis for dismissing Campbell's plea to register and enforce the ruling. ${ }^{97}$ The Court held that while the SADC states are unquestionably subject to the Tribunal's jurisdiction, this does not make the registration and enforcement of its decisions automatic or inevitable. Instead, Article 32(1) of the Tribunal

93. Id. at $85-87$.

94. See Richard Frimpong Oppong, Enforcing Judgments of the SADC Tribunal in the Domestic Courts of Member States, in Monitoring Regional Integration in Southern Africa YeARBOOK 2010, at 115 (Anton Bösl, Andre du Pisani, Gerhard Erasmus, Trudi Hartzenberg \& Ron Sandrey eds., 2011).

95. Quoted in Alice Chimora, SADC Tribunal's Ruling on Zimbabwe Overridden by Court, AfriK-NEws, 4 Mar. 2009, available at http://www.afrik-news.com/article15378.html.

96. OSJI, supra note 84, at 16, 19-20, 24.

97. Gramara (Pvt) Ltd v. Government of the Republic of Zimbabwe (HC 33/09) [2010] ZWHHC [Harare High Court] 1. 
Protocol stipulates that this process is governed by the rules of civil procedure relating to the registration and enforcement of foreign judgments in member states. In Zimbabwe, as in South Africa, a foreign judgment cannot be registered and enforced if it is in conflict with public policy or an overriding statute. In principle, the Court observed, it would generally be contrary to public policy for a state to violate its international obligations within the domestic realm. As a general rule, Zimbabwe should therefore abide by the Tribunal's judgments. In the Campbell case, however, the enforcement of the Tribunal's ruling would be in conflict with the Constitution, under whose terms the land seizures had taken place; it would undermine the authority of the Supreme Court, which had affirmed the constitutionality of the land seizures; it would force the government to contravene constitutional provisions enacted by parliament; and it would lead to the eviction, upheaval, and relocation of most of the beneficiaries of the land reform program. ${ }^{98}$ The Court concluded that enforcement of the Tribunal's decision would thus be fundamentally contrary to public policy. ${ }^{99}$

The fourth category of factors covers the regional human rights system's mechanisms and procedures for monitoring and following up on state implementation of regional court judgments. In the Council of Europe system, monitoring and follow-up of the judgments of the European Court of Human Rights are undertaken by the Committee of Ministers, formed for this purpose under the European Convention on Human Rights; the Council's Department for the Execution of Judgments, which assists the Committee of Ministers; the Parliamentary Assembly and its Committee on Legal Affairs and Human Rights; and the European Commissioner for Human Rights. ${ }^{100}$ The combined efforts of these bodies exert political pressure on states that have not adhered to court judgments. In the SADC system, the regional follow-up mechanism is limited to the Summit's discretionary power to take "appropriate action" in the event of non-compliance with a Tribunal ruling. ${ }^{101}$ The Summit could have applied pressure on Zimbabwe but chose not to do so.

The Summit's stance draws attention to a set of factors that are not explored in the OSJI study. The implementation of regional judicial decisions depends not only on the political character of individual states, but also on the political character of the regional organization as a whole. The communal character is a product of history, ideology, and inter- and intrastate politics. These dynamics shape the organization's norms, values and priorities, the content and status of its legal instruments, and the nature and application of

\footnotetext{
98. Id.

99. Id.

100. OSJI, supra note 84 , at 45-61.

101. SADC, Protocol on Tribunal, supra note 20, art. 32.
} 
any collective enforcement mechanisms. We have seen that the Tribunal crisis is not explicable solely with reference to Zimbabwe's disregard for human rights and the rule of law. It also emanated from the Summit's preoccupation with solidarity and sovereignty, which flows from the region's political economy, global weakness, and historical struggle against colonialism.

A comparison with the EU is instructive here because SADC was modeled on the European Community and the SADC Tribunal was modeled on the ECJ. ${ }^{102}$ Over the past few decades, the ECJ has asserted the primacy of European Community law over national legislation. Interpreting EU treaties as if they amounted to a de facto constitution for Europe, the ECJ has often declared national legislation and conduct to be invalid on the grounds that they are "EU-unconstitutional."103 The EU member states have assented to this intrusive role of the Court, which chips away at sovereignty, not simply because they are committed to integration and hence to the development and implementation of community law, but also because they endorse the values enshrined in that law. The key values are captured in the 1992 Treaty on European Union, which declares that "the Union is founded on the principles of liberty, democracy, respect for human rights and fundamental freedoms, and the rule of law, principles which are common to the Member States."104 Precisely because these principles are indeed common to member states, the EU enjoys sufficient normative congruence and trust to have established a viable regional court and other bodies with supranational authority. ${ }^{105}$

There is no comparable normative congruence and trust in Southern Africa. The region encompasses diverse political systems, which precludes the SADC states from being bound-either in the sense of being united or in the sense of being constrained-by the democratic principles espoused in the SADC Treaty. The political diversity, coupled with the states' shared commitment to "strict respect for sovereignty,"106 also precludes the possibility of having a viable supranational court whose jurisdiction covers respect for human rights and the rule of law.

102. Lenz, supra note 8.

103. Geoffrey Garrett, R. Daniel Kelemen \& Heiner Schulz, The European Court of Justice, National Governments, and Legal Integration in the European Union, 52 INT'L ORG. 149 (1998). See also Karen Alter, The European Court's Political Power: Selected Essays (2009).

104. Treaty of Amsterdam Amending the Treaty on European Union (1997), art. 6(1), available at http://eur-lex.europa.eu/en/treaties/dat/11997D/htm/11997D.html.

105. See Marise Cremona, Variable Geometry and Setting Membership Conditionalities: A Viable Strategy?, in Regional Integration in Southern Africa: Comparative international perspecTIVES 193 (Christopher Clapham, Greg Mills, Anna Morner \& Elizabeth Sidiropoulos eds., 2001).

106. SADC, Protocol on Politics, supra note 18, pmbl. 


\section{CONCLUSION}

The SADC states created a legal framework that embraced human rights and democracy not because they were collectively committed to these norms, but because there were significant political and economic costs associated with a non-democratic posture. Adopting a treaty and protocols that eschewed democracy would have been detrimental to the organization's international standing and the ability of its member states to obtain donor funding for national and regional projects. Constructing a legal edifice supportive of democracy, on the other hand, was not prejudicial to the nondemocratic countries as the Summit did not hold them accountable for breaching the Treaty.

In general, then, the contradiction between the democratic legal instruments and the undemocratic behavior of the illiberal states was not troubling for these states or the Summit. This changed dramatically with the Tribunal's rulings against Zimbabwe. Because of the court's status, the rulings exposed the contradiction in a fashion that was unprecedented and inescapable. Whereas the Summit could confidently ignore or trivialize the criticism of Harare emanating from Western capitals and local politicians and activists, it could not do this with respect to the Tribunal's findings because the regional court was a creature of the Treaty, it was set up by the Summit, and it comprised Southern African judges appointed by the heads of state. Moreover, unlike the criticism of Zimbabwe by human rights groups and Western governments, the court's judgments would endure until they were complied with or nullified. The judgments thus generated a number of tensions-between state sovereignty and the Tribunal's authority; between the realpolitik of the Summit and the legal character of the Treaty; and between the norms of regime solidarity and the rule of law-that could not be left unresolved indefinitely. Unable to evade or transcend these tensions, the Summit disbanded the Tribunal.

The dissolution of the Tribunal highlights the primary feature of regional organizations, namely that they are forums of sovereign states. Their character, goals, and strategies are determined by their members and they have no authority, power, or capacity other than that conferred on them by their members. ${ }^{107}$ After the Tribunal was disbanded, its judges complained that the Summit believed it was all-powerful and unaccountable when in truth its actions were constrained by the Treaty. ${ }^{108}$ This perspective was plainly wrong on the facts. The Summit demonstrated unequivocally that it is not

107. Laurie Nathan, The Peacemaking Effectiveness of Regional Organisations, 81 WorkING PAPER (2010), Crisis States Research Centre, London School of Economics.

108. Pillay, Kambavo, Tshosa \& Chomba, supra note 49. 
subordinate to the Treaty. In an international system in which state sovereignty is a paramount factor, the Summit and its member states are constrained only if, and to the extent that, they consent to be constrained. Such consent has not been given in Southern Africa and will not be forthcoming for the foreseeable future. 